\title{
Organizational Learning: As an Approach for Transforming to the Learning Organization Concept in Saudi Universities
}

\author{
Fatimah Mohammed Sabiq AL-Qahtani \\ Master of Educational Planning and Administration \\ Dr. Salah El Din Abd El Aziz Ghoneim \\ Associate Professor of Educational Planning and Administration \\ Head of the Educational Planning Unit \\ National Center for Educational Research and Development, Cairo
}

Doi:10.5901/mjss.2013.v4n2p513

\begin{abstract}
The aims of this study were to define the reality of applying the organizational learning as an approach for transforming to the learning organization concept, determine the important obstacles which appeared when applying it, and identify the suggestions which may contribute in applying it at Al-Imam Muhammad ibn Saud Islamic University from the point of views of its faculty members. A descriptive method is used (survey) and a questionnaire of (60) statements had been answered by (200) of the faculty members. The most important results of the study have revealed the practice of organizational learning process (with a weak degree) at the university, and the presence of obstacles (with a high degree) that limiting the application of the organizational learning at the university, and the acceptance of proposals (with a very high degree), which may contribute to the application of the organizational learning process, and there are statistically significant differences in favor of females in the dimension of: (enhancing the organizational learning process), and in the dimension of:(provision a collective learning environment in the university), which represent the reality of organizational learning at the university. There are also statistically significant differences in favor of human sciences specializations in proposals for the application of organizational learning. The study recommended that the academic leaders at the Ministry of Higher Education and Saudi universities must work to promote the organizational learning culture and the concept of learning organization among the faculty members and university employees, and provide an environment that facilitates the organizational learning process at the university, and the establishment of academic departments specializing in the science of Learning organizations and organizational learning at universities as well as the establishment of the organizational learning centers within the university, staffed by experts and advisors in organizational learning, and provide counseling and guidance services for all employees at the university, and also for beneficiaries from outside the university.
\end{abstract}

Keywords:organizational learning, Learning Organization, Saudi Universities, Al-Imam Muhammad ibn Saud Islamic University.

\section{Introduction}

With the beginning of the new millennium, organizations sought to search about the latest management systems, in order to ensure the transition to a knowledge-based society which depending in its economy on producing knowledge instead of capital or labor force. Communities began reviewing their educational systems administration, to improve their learning outcomes (Gibran, 2011, p. 428). Since the organization which will success in the future is the one which can discover how to benefit from the learning capabilities of all its members (Al Suwaidan, 2012, p. 58). The establishment of specialized organizations in organizational learning and Learning organizations field has supported this trend, as (SOL) (The International Society for Organizational Learning (SOL, 2012), and (European Consortium for the Learning Organization) (ECLO, 2012).

The twenty-first century witnessed a global competition in the university learning environment because of progress in technique and knowledge. Where the higher education systems became exposed to job stresses which made 
universities administrations concerned about applying the recent trends: such as organizational learning and Learning organizations concept to keep up with global changes (Alhawwagera, 2010, p. 15). Universities are one of the most influential organizations in the community; their success depends on their ability to face the rapid changes (Hussain, 2007, p. 11). (Sultan and khedr, 2010, p. 149) emphasize that universities should change their administrative systems, obtain the concepts of the Learning organizations; for development and performance improvement. Where (Elmelegy, 2011, p. 231) shows that applying the concept of Learning organizations to universities is through continuous learning, throng abandonment of traditional management practices, and adopting models and modern administrative approaches such as: the process of organizational learning, and knowledge management.

In Saudi Arabia, the higher education has a good awareness from the country, the Ministry of Higher Education (which was established in 1975) has expanded to establish universities, where in 2011 their number reached (34) Universities (Ministry of Higher Education, 2011). Although there are interested in universities development; however, the current reality of Saudi universities point to an existence of a real gap between what is currently available, and what is desired in future. Where the results of (Mutairi, 2010) study has showed weakness in information sharing, and electronic networking among university departments. This study recommended need for applying organizational learning in Saudi universities; to reduce the number of management levels, avoid centralism, and facilitate the transition to Learning organizations. Based on the Ninth Development Plan of the Kingdom of Saudi Arabia (2010 -2014) in Chapter (12) in human resources development in the higher education field, appeared some objectives of higher education: application of administrative systems to develop universities, and optimum use of technical devices to produce knowledge within them (Ministry of Economy and Planning, 2010, p. 390). From this point of view, this study tries to recognize the reality of organizational learning; it is applying obstacles, and identifies suggestions that may contribute in applying it at the University of Al-Imam Muhammad Ibn Saud Islamic University in Riyadh from the point of view of its faculty members.

\section{Purpose of the study}

This study aims to present suggestions contribute in applying organizational learning for transforming to the concept of Learning organizations at the University of Al-Imam Muhammad ibn Saud Islamic University from the point of view of its faculty members; represented as the following:

- Recognizing the reality of applying organizational learning for transforming to the concept of the Learning organizations.

- Identifying organizational learning applying obstacles for transforming to the concept of the Learning organizations.

\section{Study questions}

he study problem is determined by the following questions:

1- What is the reality of applying organizational learning for transforming to the concept of learning organization at the University of Al-Imam Muhammad ibn Saud Islamic University from the point of view of its faculty members?

2- What are the obstacles of applying organizational learning for transforming to the concept of learning organization at the University of Al-Imam Muhammad ibn Saud Islamic University from the point of view of its faculty members?

3- What are the suggestions that may contribute in applying organizational learning, for transforming to the concept of learning organization at the University of Al-Imam Muhammad ibn Saud Islamic University from the point of view of its faculty members?

4- Are there statistically significant differences at level of $(0.05)$ or less, between the point of views of the faculty members on: the reality of organizational learning, its applying obstacles, and suggestions that may contribute in applying it at Al-Imam Muhammad ibn Saud Islamic University, according to differences in their personality and professional variables: (sex, grade, years of experience, and specialization)?

\section{Importance of the study}


(Theoretical importance): It lies in the added knowledge, by defining the organizational learning process and the Learning organization concept, emphasizing the importance of applying organizational learning, as an essential input for transforming universities to Learning organizations seeking to develop the skills of workers, improving the level of their learning constantly, and representing some recent experiences of universities that have applied organizational learning and the concept of the learning organization, to benefit from them.

(Applicable importance): It has been expected to benefit from the current study each one of: decision-makers and academic leaders at the Ministry of Higher Education at Saudi universities administrations, and that by emphasizing the importance of applying the concept on universities and to benefit from the results and recommendations of the study, employees of the university:(faculty members, staff and administrators), students and community members through encouraging them to contribute in submitting their opinions and suggestions, and researchers and scholars for conducting more research in the field of learning organizations sciences and organizational learning.

\section{Limitations of the study}

(Objective limits): the study objective limits were in knowing the reality of organizational learning, its most important applying obstacles, and suggestions that may contribute in applying it at the University of Al-Imam Muhammad ibn Saud Islamic University.

(Spatial limits): the application of the study was limited on the University of Al-Imam Muhammad ibn Saud Islamic University in Riyadh.

(Temporal limits): this study has been applied at the beginning of the second semester of the academic year 2011/2012.

\section{6 - General Framework of the Study}

\subsection{Organizational learning:}

Organizational learning and Learning organizations Concepts has published in (1963). Their definitions appeared in the writings of (Cyert \& March), (Argyis \& Schon) (1978), Peter Senge (Senge, 1990) and Marqurdat (Marqurdat, 1996 ). In the end of the nineties the organizational learning and Learning organizations became one of the fundamental concepts that managers, researchers and practitioners were interested about (Ayoub, 2004, p.67). The initial beginning of the definition of organizational learning have focused to improve the performance of the organization, and the most prominent was the definition of (Cyert \& March) as " an adaptive behavior of the organization to adapt to the environment over time", then definitions headed toward using knowledge, including the definition of Hedberg (Hedberg, 1981) that " Organizational learning is the process of acquiring and processing information by members of the organization, through their interactions with the environment, in order to increase their ability to understand reality and know the results of their actions"(Abukhaddar, 2007, p. 20-27). In the nineties came Peter Senge (Peter Senge, 1990), who is the creator of the learning organization concept and the pioneer in the organizational learning field, he presented his book (The Fifth Discipline) in (1990) and stated that the organizational learning is the means by which individuals are detected in organizations constantly and how they form and change the reality of their work place (Senge, 1990, p. 6).

The researchers found differences in definitions, according to differences in researches point of views, specialties, and their perspective of learning concept.

Based on the above information, the organizational learning has defined in this study procedurally as: a continuous collective learning process which all the university employees, leaders, faculty members, staff and administrators, have based on a shared vision to transform the university to learning organization, through the university administration work in a regulatory collaborative culture framework to allow workers to self-learning and continuous collective learning, by facilitating their acquisition of knowledge, managing and exchanging it via modern electronic techniques, and informing them on the previous experiences of the University and other universities that are stored in its organizational memory to get benefit from them.

The importance of organizational learning, as the most important administrative approach as it links between learning and the organization through its interest in the individuals' management of organizations (Abu Shandi, 2011, p. 16). However; transforming universities to learning organizations, will not solve all their problems, but working on applying organizational learning, is certainly an important first step (Manlow and Friedman, 2010, p. 49). 
Organizational learning includes a number of properties that has agreed by (Altaweel and Ababneh 2009, p.73; Abukhaddar, in 2007, p. 32; Abu Alnasr, 2008, p.150) including: organizational learning automatically and continuously occurrence between organization members who are themselves have common vision towards the objectives of the organization and its future. In addition to that organizational learning is a complex process needs planning, organization, follow-up and evaluation from its leaders, including acquisition and storing of information in the organization's memory and then accessing it to be used in solving current and future problems. As (Hammoud, 2010, p.49) indicates that the learning organization today is based on achieving three key dimensions: Learn, Adapt and Change.

It was reported by (Watkins and Marsick) and (Nevis,) in (Abukhaddar, in 2007, p.77) the most important strategies of organizational learning occurrence, which learning continuous opportunities, encouraging them to form collective learning teams, enabling them to collect information continuously about the external environment that surrounding the organization.

There is no doubt that organizations witch applying organizational learning has encountered by many obstacles. The most important of what were agreed upon by (Abukhaddar, in 2007, p.79 to 82; Sultan and AL khedr, 2010, p 138; Baghdadi and al-Abadi, 2010, p. 40) the existence of complex organizational structures hinder the transmission of information between the administrative departments; block the experiences of individuals within their departments. As will as the existence of traditional leadership holding the old actions and out of the change, which practice the centralism decision-making and do not allow the delegation of authority, and the culture of the organization that adheres prevalent customs that does not believe in openness, participation, teamwork transparency, and considering mistakes as an opportunities for learning.

\section{2 learning Organization}

The beginning of the concept of learning organization is back to the eighties of the last century when (Shell Oil Company) started to transform to a learning organization, and it has succeeded on its competitors by two years. In the nineties, the numbers of organizations that have committed themselves to become learning organizations have grown, as: Shell Oil, Honda, Samsung (Abukhaddar, 2007, p.103).

According to Peter Senge (Senge, 1990, p. 3) learning organizations are: "organizations where people continually expand their capacity to create the results they truly desire, where new and expansive patterns of thinking are nurtured, where collective aspiration is set free, and where people are continually learning to see the whole together". While "Burgoyne and Boydell" (Altaweel and Ababneh, 2009, p.86) defined it as" the organization that facilitates the learning of all its members constantly; in order to achieve its strategic objectives".

Based on this information, learning organization in this study has defined procedurally as: the organization that works to improve the utilization constantly energies employees, providing for an environment that supports and facilitates a learning processes, and by encouraging their members to move toward self-learning and collective continuous and teamwork, and involvement in the development of strategic plans and decision-making, and give them full powers, to take advantage of new technologies, knowledge management and information storage in memory regulatory and exchange of expertise and experience outstanding with local organizations and the World; for the success of the organization in achieving its goals: to improve continuously the quality of performance workers, and quickly adapt to global changes, and persistence in the face of various challenges.

The learning organization is characterized with opportunities as: its ability to a comprehensive learning on the level of individuals ,groups and organization, the existence of a shared vision for individuals and teamworks, the presence of communication system that maintain the flow of knowledge and information, and the use of organized style to solve problems (Altaweel and Ababneh, 2009, p.89). Also, as the administrations levels in the learning organizations are few, the administration style depends on sharing and the teamwork are interactive in decision making (Marqurdat, 2002 p.25). Many researchers and scientists of administration formulate different models to build a learning Organization, where it is unable for organizations to get a single model; each organization has nature of composition and management differs from other. From these models emerged typical: Senge (1990) and Marquardt (2002). Senge's Model consisted of five dimensions which are: systems thinking, personal mastery, mental models, shared vision and team learning (Senge, 1991, p. 139), where Marquardt Model consisted of five subsystems are: are people, organization, knowledge, technology, and learning (Marquardt, 2002, p. 25). 


\subsection{Universities as learning organizations}

The institutions of higher education are consider the center for educational and political decision-making, where (Tayl, 2006, p.135) sees that they provide community, with learners, leaders, politicians and business leaders and where its researches aim to discover knowledge and technique; therefore universities asking for a permanent seek for development. (Ahmed, 2005, p.319) ensures that global variables have imposed on universities to transform from reactive and slow response to an effective management always seeks for changing and constant renewal.

In this view we find that learning university is considered as a special model among other universities with comprehensive characterizations for all administrative processes; as knowledge maker which offers a lot of discoveries to society and scientific and mental creations (Elmelegy, 2011, p. 141). The work environment of learning university is characterized by confidence and cooperation, encouraging individuals to make questions, discussions, and criticizing thinking, contributing in decision-making, offering feedback and solving problems all over the university according to a systematic plan (sultan and khedr, 2010, p.75).

\subsection{Sme experiments of international universities that applied organizational learning for transformation to the concept of learning organizations}

Reviewing the experiences of universities that applied the concept for transformation to learning organizations is an important issue to benefit from their ideas and mistakes. Experiments of two worlduniversities that applied organizational learning process, have presented, namely:

A - Lancaster University UK: Hasestablished two departments: (Department of organization, work and technology) and (Department of Administration Development), also it made (Center for the Study of technology and organization) (CSTO),which is specialized in organizations in order to scientific search at organizations and in administrative inputs that is suitable for their development, provide studies on the relationship between technology and organizations, and to teach learning and departments development. Experts are collaborating from faculty members at the center, to provide their modern ideas to learners as leaders, workers at organizations and postgraduate students, through consulting (Lancaster University, 2012).

B - Experience of University of Kansas U.S.: university administration has applied the process of organizational learning in a planned and systematic and thoughtful at the center (information services) of the unit (Information Technology and Libraries) within the university (University of Kansas, 2012). The experiment aimed to consolidate and promote organizational learning at work. .The university also established (OD group of leaders) Organizational Development Group for leadership that focused on the development of plans and strategies to promote organizational learning (Goodyear \& others, 2006, p. p. 5- 15).

Through the previous representation of the two experiments, the researchers see that universities in Saudi Arabia can benefit from these two experiences represented in establishing specialized academic departments in the learning organizations and the organizational learning sciences which represent courses to postgraduate, or grant diplomas specialized in leadership, which can be attended by who is intended in these studies from university students or outside organizations such as: banks, companies and others. As well as working on the establishment of committees and teams of Administrative Sciences, which work on designing programs to promote organizational learning levels among university employees, at all administrative levels.

\subsection{The model which used in the present study}

This study aims to identify the reality of organizational learning in universities, considering it the suitable approach for transforming the universities to the concept of the learning organization. Through reviewing of the educational literature, it has been found that learning process means knowledge and information. My point here is that learning organization is building mainly on knowledge management, by using modern information technology, and that the two former models: of Senge (1990) - and Marquardt (2002), consist of systems and elements which are their concepts have been changed in contemporary organizations.

Therefore, in an attempt to reach a model that can be used to determine the most important practices of organizational learning process, which have the building elements for learning organization contemporary universities. Also, I benefit from the organizational learning literature, where I invoked to the typical: Senge (1990) - and Marquardt (2002) to build a learning organization, consulted some experts in organizational learning and learning organizations field 
from local and international universities, and I have stated four basic dimensions designed as in Figure (1) include the most important practices that show the reality of applying organizational learning in universities, namely:

The first dimension: (Enhancing Organizational learning), which means that the university administration adopting and consolidating learning methodology (individual, collective, and organizational) between all of its employees of leaders, faculty members, staff, administrators and students. The second dimension: (Organizing Team Learning) which means the organization of individual self-learning in a collective manner frame with a teamwork. Third dimension: (providing a Team Collective learning environment in the university) it means any environment that is empty from workers fear from experimenting new ways of work, empty from leaders' harsh criticism upon employees in the organization, and rewards achievement and professional excellence. Fourth Dimension: (Activating Collective participation in knowledge management) by enabling all the university access employees information and knowledge that related to the university, and transferring them by using modern techniques.

Figure (1) explains the organizational learning dimensions at universities for transforming to the learning organizational concept.

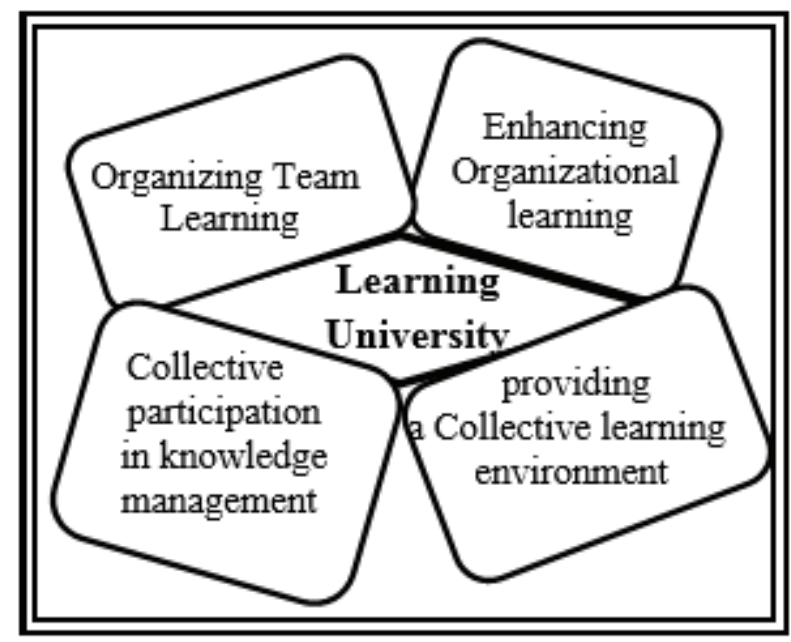

Source:from the researchers design after consulting experts in organizational learning and learning organizations field from local and international universities, and based on the models of Peter Senge (1990) and Marquardt (2002) for building the organizational learning .

\subsection{Rrevious studies}

Newly emerged several studies and research confirm that organizational learning is considered as one of the most important trends in contemporary management; which were different in their goals from the goals of this current study which is directed to universities as learning organizations. The previous studies will be represented according to the studies that generally addressed the organizational learning and learning organization in different businesses companies and then to the studies that dealt with the same subject at universities specifically.

One of the studies that have been applied in business foundations, came the study of (Weldy, 1990) with the title of " Learning Organization and Transfer: Strategies for Improving Performance". This study aimed to reveal the nature of the relationship between learning organization and the transformation process, as a strategy to increase learning and activation of knowledge management in business companies in Los Angeles in the United States of America. The questionnaire was applied to (143) employees. The most important results confirmed that the transition to the concept of learning organization is one of the most important factors which improve companies' performance and achieve excellence. In the same context the study of (Zayed et al, 2009) with the title of (Learning Organization and its applications in the Kingdom of Saudi Arabia), which aimed to introduce the concept of learning organization and 
characteristics, and its presence in basic sectors at Royal Commission in Jubail in Saudi Arabia. Such study has been applied on 321 employees. The results found that the learning organization few available dimensions: directing individuals towards a shared vision, and create knowledge and learning systems, while the more available dimensions is encouraging inquiry and dialogue. In the same field (Davis and Dally, 2008) made a study with the title of "The Learning Organization and its Dimensions as key Factors in Firms' Performance". This study has been designed to test the relationship between the dimensions of the learning organization and the percentage of sales from new products in some money institutions and banks in the United States of America. The questionnaire was applied on a sample of human resource managers and marketing managers. It is most important results was existence of a positive correlation between the dimensions of learning organization and the financial performance of those companies, where institutions returns were increasing whenever the concept of learning organization, has been applied.

In the field of application university on (Abu-tina,2011) made a study named as:" Exploring the Relationship between Organizational Learning and Career Resilience among Faculty Members at Qatar University" which aimed to identify the level of practicing the organizational learning and its impact on the functional flexibility among faculty members, and discover the relationship between them at Qatar University. The questionnaire was applied to a sample of (400) members. And the findings indicated that the faculty members at the University of Qatar practice three different levels of organizational learning (individual, collective, and organizational) which were of moderate degree. According to (Mutairi, 2010), a study entitled (organizational learning at King Saud University from its workers point of view), which aimed to recognize the availability of organizational learning with its three dimensions (strategic, organizational, cultural) at King Saud University in Riyadh. The questionnaire was applied on a sample of (400) members from the employees of the university of administrative, staff, and faculty members. Its most important findings are: the process of the organizational learning is happened as moderate degree at King Saud University.

In the same vein (Portfelt, 2006) study which entitled (The University; A Learning Organization) aimed to discover the availability of the theoretical model characteristics of the learning organization, and knowledge these characteristics support hinder the organizational learning process at Karlstad University in Sweden. The questionnaire was applied and interviews on all university employees. And the findings indicated the availability of theoretical model characteristics of the learning organization moderate degree at the university, neglecting of the feedback, the existence of lack in university internal environment information, and the non-application of organizational thinking in solving problems.

And also in the field of application on universities Reese (Reece, 2004) conducted a study entitled.

Universities as Learning Organizations: How Can Australian Universities Become Learning Organizations? which aimed to identify the way in which Australian universities can be transformed to Learning Organizations. Personal interviews were conducted with (32) members of the administrative staff at Western Australia universities. The findings indicated that the most characteristics of the learning organization that noticed by study members are respectively as follows: leadership, shared vision, and the providing of the organizational culture.

In light of the above display of the previous studies, researchers have got benefited this current study from the previous studies in determining the problem of the study, designing the search instrument, choosing the correct approach, and discussing the results of the current study.

In the conclusion of the above general Framework of this Study, the researchers' point of view is that the information era has been imposed on all organizations, especially the universities, the need for changing their practices, and the development of university departments, in order to improve their management performance and the overall development of society.

\section{7- Methodology}

\subsection{Methodology/approach}

This study is quantitative in nature and was conducted using a survey methodology as its research design.

\subsection{Sample}

Participants of this study were faculty members of all colleges and programs at Al-Imam Muhammad ibn Saud Islamic University, during the academic year 2011 / 2012 with number (940) members whom (820) male and (120) Female according to statistics of the University of (2010) (University of Al-Imam Muhammad ibn Saud Islamic university, 2011). 
Table 1 Illustrates the study community and total number of sample and its percentage according to gender.

\begin{tabular}{|c|c|c|c|c|}
\hline Gender & $\begin{array}{c}\text { Community Total } \\
\text { number }\end{array}$ & percentage & Samples Total number & percentage \\
\hline Male & 820 & $87 \%$ & 124 & $62 \%$ \\
\hline Female & 120 & $13 \%$ & 76 & $38 \%$ \\
\hline Total & 940 & $100 \%$ & 200 & $100 \%$ \\
\hline
\end{tabular}

Because of the large size of the study community, and according to (Assaf, 2006, p. 65): this kind of sample depends on the size of the study population, if it was great, then we select a representative sample of the community so that opportunity of any member of the study community to be chosen as a member of the study sample is equal. With the number of (940) members, a representative sample of the study community has been selected with number of (282) members, representing (30\%) of the original study community. The researchers have distributed (734) questionnaire on the faculty members in order to avoid the lack of response or loss of questionnaires, and this is what had happened. The returning questionnaires were $(200)$ representing $(71 \%)$ of the size of the sample and $(21 \%)$ of the study community. The raw data of the sample has been rated according to the following classificatory variables: (Gender - Degree - Years of Experience - Specialty) which are reflected in Table (2) as follows.

Table 2 Represents the sample of the study according to gender, scientific degree, years of experience, and specialty.

\begin{tabular}{|c|c|c|c|c|c|c|c|}
\hline Variable & Levels & No. & percentage & variable & levels & No. & percentage \\
\hline \multirow{5}{*}{ Gender } & \multirow{3}{*}{ Male } & \multirow{3}{*}{124} & \multirow{3}{*}{$62 \%$} & \multirow{5}{*}{$\begin{array}{c}\text { Years of } \\
\text { experience }\end{array}$} & Less than 5 years & 47 & $23.5 \%$ \\
\hline & & & & & From 5 to 10 years & 41 & $20.5 \%$ \\
\hline & & & & & From 10 to 15 years & 30 & $15 \%$ \\
\hline & Female & 76 & $38 \%$ & & More than 15 years & 82 & $41 \%$ \\
\hline & Total & 200 & $100 \%$ & & Total & 200 & $100 \%$ \\
\hline \multirow{5}{*}{$\begin{array}{c}\text { Scientific } \\
\text { degree }\end{array}$} & Professor & 34 & $17 \%$ & \multirow{5}{*}{ specialty } & \multirow[b]{3}{*}{ Human science } & \multirow{3}{*}{163} & \multirow{3}{*}{$\begin{array}{l}\% 81,5 \\
81.5 \%\end{array}$} \\
\hline & $\begin{array}{l}\text { Associate } \\
\text { professor }\end{array}$ & 41 & $20.5 \%$ & & & & \\
\hline & $\begin{array}{l}\text { Assistant } \\
\text { Professor } \\
\text { (Lecturer) }\end{array}$ & 125 & $62.5 \%$ & & & & \\
\hline & \multirow{2}{*}{ Total } & \multirow{2}{*}{200} & \multirow{2}{*}{$100 \%$} & & Natural science & 37 & $18.5 \%$ \\
\hline & & & & & Total & 200 & $100 \%$ \\
\hline
\end{tabular}

\section{3 the study instrument and data collection}

A closed questionnaire has been designed, the number of it is phrases was (60) phrases. It has been divided into three major aspects: firstly, the reality of the applying the organizational learning for transforming to learning organization concept at University of Al-Imam Muhammad ibn Saud Islamic University, contained (30) phrases. Second: The obstacles of applying of the organizational learning for transforming to learning organization concept at University of Al-Imam Muhammad ibn Saud Islamic University, which contained (18) phrases. Finally: the suggestions which may contribute in applying the organizational learning for transforming to learning organization concept at University of Al-Imam Muhammad ibn Saud Islamic University, which contained (12) phrases.

Also, the faculty potentially answers have been identified according to the Likert scale quintet. Phrases gradually arranged in varying approval of the following: (strongly agree - I agree - somehow agree- Disagree - strongly disagree). And to make sure about validation of the questionnaire, it has been offered to (32) arbitrators and experts in organizational learning and learning organizations field from local and international universities. In order, to make sure of the dimensions which are identified by the researchers, and give their comments on the phrase and the degree of their suitability for the belonging axis. 
Based on the remarks and suggestions which added by the arbitrators, the researchers have made the modifications that agreed upon by the majority of the arbitrators.

To measure the degree of sincerity of internal consistency of the questionnaire, we used correlation coefficient Pearson, it has been shown calculates values correlation coefficients between each of the phrases axis, and the total score of the center to which it belongs, that all the resulting values were positive and statistically significant at the level of (0.01). Which shows the sincerity of the phrases in the measurement of the goal and it was placed. And also in order to make sure of the reliability of questionnaires was used Cronbach's alpha equation, by measuring the stability of each of the pivot-resolution. Has got a resolution, as the College reliability coefficient ranged of $(0.90)$ to $(0.94)$ It is considered the overall values indicate that the high-resolution enjoys a high degree of stability can be relied upon when the application field of study.

The application procedures have been done as follows: After getting the permission to applying the questionnaire, it distributed on faculty members in all the university faculties directly via, handling, and indirectly through E-mail. And also, designed an electronic questionnaire, and telephone communication has been used, to follow the arrival of questionnaires, and to ensure getting large number of respondents. The number of distributed questionnaires was (734) questionnaire. The number of collected questionnaires was (200) questionnaire, unloading data and a statistically treating have been done using (SPSS) (Statistical package for social sciences). A variety of statistical techniques to analyze the data were used, which are: frequencies, percentages, Arithmetic mean (Mean), and the weighted arithmetic mean, standard deviation, ranks style, ( $T$ - test) to see significant differences between the arithmetic means, and (P-test)(oneway ANOVA). The Value $(a<0.05)$ has used to describe the result statistically by function.

To determine the standards of approval degree of the faculty members about the study, the method for calculating range had been used, as the following: from (1) to (1.80) represents (strongly disagree), from (1.81) to (2.60) represents (disagree), from (2.61) to (3.40) represents the (somewhat agree), from (3.41) to (4.20) represents (agree), and from (4.21) to (5.00) represents (strongly agree).

\section{8 - Results and discussion}

8.1 What is the reality of applying of organizational learning for transforming to the concept of learning organization at the University of Al-Imam Muhammad ibn Saud Islamic University from the point of view of faculty members?

To answer this question it has been used: frequencies, percentages, and arithmetic means, standard deviations, and ranks style to arrange phrases.

The results of the answer to this question were as shown in Table No. (3). 
Table 3 shows the opinion of the faculty members on the first axis: "the reality of applying of organizational learning"

\begin{tabular}{|c|c|c|c|c|c|c|c|c|c|c|}
\hline \multirow[t]{2}{*}{ s } & \multirow{2}{*}{\multicolumn{2}{|c|}{ Phrase }} & \multicolumn{5}{|c|}{ Degree of Agreement } & \multirow[t]{2}{*}{ average } & \multirow{2}{*}{$\begin{array}{l}\text { Normative } \\
\text { deviation }\end{array}$} & \multirow[t]{2}{*}{ ORDER } \\
\hline & & & $\begin{array}{c}\text { Strongly } \\
\text { agree } \\
\end{array}$ & agree & $\begin{array}{c}\text { Somehow } \\
\text { agree }\end{array}$ & Disagree & $\begin{array}{l}\text { Strongly } \\
\text { Disagree }\end{array}$ & & & \\
\hline \multicolumn{11}{|c|}{ First dimension phrases (Enhancing Organizational learning). } \\
\hline \multirow[t]{2}{*}{1} & \multirow{2}{*}{$\begin{array}{l}\text { Our university adopts the concept } \\
\text { of organizational learning. }\end{array}$} & $\mathrm{K}$ & 17 & 55 & 82 & 31 & 15 & \multirow[t]{2}{*}{3.14} & \multirow[t]{2}{*}{1.02} & \multirow[t]{2}{*}{4} \\
\hline & & $\%$ & 8.5 & 27.5 & 41 & 15.5 & 7.5 & & & \\
\hline \multirow[t]{2}{*}{2} & \multirow{2}{*}{$\begin{array}{l}\text { Our university interested in } \\
\text { transforming to learning } \\
\text { university. }\end{array}$} & $\mathrm{K}$ & 33 & 62 & 71 & 21 & 13 & \multirow[t]{2}{*}{3.40} & \multirow[t]{2}{*}{1.08} & \multirow[t]{2}{*}{1} \\
\hline & & $\%$ & 16.5 & 31 & 35.5 & 10.5 & 6.5 & & & \\
\hline \multirow[t]{2}{*}{3} & \multirow{2}{*}{$\begin{array}{l}\text { Our university applies the latest } \\
\text { learning methods in the modern } \\
\text { management. }\end{array}$} & $\mathrm{K}$ & 10 & 45 & 60 & 55 & 30 & \multirow[t]{2}{*}{2.75} & \multirow[t]{2}{*}{1.11} & \multirow[t]{2}{*}{9} \\
\hline & & \begin{tabular}{|l|}
$\%$ \\
\end{tabular} & 5 & 22.5 & 30 & 27,5 & 15 & & & \\
\hline \multirow[t]{2}{*}{4} & \multirow{2}{*}{$\begin{array}{l}\text { Our university designs programs } \\
\text { to enhance organizational learning } \\
\text { culture }\end{array}$} & $\mathrm{K}$ & 8 & 50 & 68 & 54 & 20 & \multirow[t]{2}{*}{2.86} & \multirow[t]{2}{*}{1.03} & \multirow[t]{2}{*}{7} \\
\hline & & $\%$ & 4 & 25 & 34 & 27 & 10 & & & \\
\hline \multirow[t]{2}{*}{5} & \multirow{2}{*}{$\begin{array}{l}\text { Our university develops our } \\
\text { feeling about the importance of } \\
\text { self learning. }\end{array}$} & $\mathrm{K}$ & 17 & 65 & 51 & 45 & 22 & \multirow[t]{2}{*}{3.05} & \multirow[t]{2}{*}{1.15} & \multirow[t]{2}{*}{5} \\
\hline & & $\%$ & 8.5 & 32.5 & 25.5 & 22.5 & 11 & & & \\
\hline \multirow[t]{2}{*}{6} & Our university is interested about & $\mathrm{K}$ & 24 & 62 & 59 & 37 & 18 & 3.18 & 1.14 & 3 \\
\hline & developing our professional skills & $\%$ & 12 & 31 & 29.5 & 18.5 & 9 & & & \\
\hline 7 & Our university adapts with the & $\mathrm{K}$ & 24 & 34 & 75 & 53 & 14 & 3 & 1.09 & 6 \\
\hline & different changes rapidly. & \begin{tabular}{|l|}
$\%$ \\
\end{tabular} & 13 & 17 & 37.5 & 26.5 & 7 & & & \\
\hline 8 & Our university owns an & $\mathrm{K}$ & 10 & 40 & 80 & 39 & 31 & 2,79 & 1.08 & 8 \\
\hline & $\begin{array}{l}\text { organizational memory to store its } \\
\text { information and problems } \\
\text { constantly. }\end{array}$ & $\%$ & 5 & 20 & 49 & 19.5 & 15.52 & & & \\
\hline 9 & Our university is keen on & $\mathrm{K}$ & 24 & 61 & 68 & 39 & 8 & 3.27 & 1.03 & 2 \\
\hline & $\begin{array}{l}\text { exchanging experiences with } \\
\text { international universities. }\end{array}$ & $\%$ & 12 & 30.5 & 34 & 19.5 & 4 & & & \\
\hline
\end{tabular}




\begin{tabular}{|c|c|c|c|c|c|c|c|c|c|c|}
\hline \multirow[t]{2}{*}{$\mathrm{s}$} & \multirow{2}{*}{\multicolumn{2}{|c|}{ Phrase }} & \multicolumn{5}{|c|}{ Degree of Agreement } & \multirow[t]{2}{*}{ average } & \multirow{2}{*}{$\begin{array}{l}\text { Normative } \\
\text { deviation }\end{array}$} & \multirow[t]{2}{*}{ ORDER } \\
\hline & & & $\begin{array}{c}\text { Strongly } \\
\text { agree }\end{array}$ & agree & $\begin{array}{l}\text { Somehow } \\
\text { agree }\end{array}$ & Disagree & $\begin{array}{l}\text { Strongly } \\
\text { Disagree }\end{array}$ & & & \\
\hline \multicolumn{11}{|c|}{ Second dimension phrases (Organizing Team Learning). } \\
\hline \multirow[t]{2}{*}{10} & In our university, we & $\mathrm{K}$ & 16 & 44 & 68 & 49 & 23 & \multirow[t]{2}{*}{2.90} & \multirow[t]{2}{*}{1.11} & \multirow[t]{2}{*}{7} \\
\hline & $\begin{array}{l}\text { follow method of } \\
\text { collective teamwork. }\end{array}$ & $\%$ & 8 & 22 & 34 & 24 & 11.5 & & & \\
\hline \multirow[t]{2}{*}{11} & In our university, & $\mathrm{K}$ & 26 & 60 & 50 & 46 & 18 & \multirow[t]{2}{*}{3.15} & \multirow[t]{2}{*}{1,18} & \multirow[t]{2}{*}{1} \\
\hline & $\begin{array}{l}\text { collective cooperation } \\
\text { spirit prevails with our } \\
\text { leaders. }\end{array}$ & $\%$ & 13 & 30 & 25 & 23 & 9 & & & \\
\hline \multirow[t]{2}{*}{12} & In our university, we are & $\mathrm{K}$ & 14 & 37 & 55 & 70 & 24 & \multirow[t]{2}{*}{2,73} & \multirow[t]{2}{*}{1,10} & \multirow[t]{2}{*}{9} \\
\hline & $\begin{array}{l}\text { sharing with our leaders } \\
\text { decisions making. }\end{array}$ & $\%$ & 7 & 18,5 & 27,5 & 35 & 12 & & & \\
\hline \multirow[t]{2}{*}{13} & In our university, we & $\mathrm{K}$ & 10 & 53 & 63 & 57 & 17 & \multirow[t]{2}{*}{2,91} & \multirow[t]{2}{*}{1,04} & \multirow[t]{2}{*}{6} \\
\hline & $\begin{array}{l}\text { determine our shared } \\
\text { vision for its desired } \\
\text { future. }\end{array}$ & $\%$ & 5 & 26,5 & 31,5 & 28 & 8,5 & & & \\
\hline \multirow[t]{2}{*}{14} & In our university, we & $\mathrm{K}$ & 15 & 53 & 57 & 58 & 17 & \multirow[t]{2}{*}{2,95} & \multirow[t]{2}{*}{1,09} & \multirow[t]{2}{*}{4} \\
\hline & $\begin{array}{l}\text { think together to find } \\
\text { solutions }\end{array}$ & $\%$ & 7,5 & 26,5 & 28,5 & 29 & 8.5 & & & \\
\hline \multirow[t]{2}{*}{15} & In our university, we see & $\mathrm{K}$ & 13 & 60 & 67 & 44 & 16 & \multirow[t]{2}{*}{3,05} & \multirow[t]{2}{*}{1.05} & \multirow[t]{2}{*}{2} \\
\hline & $\begin{array}{l}\text { the mistake as an } \\
\text { opportunity to learn. }\end{array}$ & $\%$ & 6,5 & 30 & 33,5 & 22 & 8 & & & \\
\hline \multirow[t]{2}{*}{16} & In our university, we & $\mathrm{K}$ & 9 & 35 & 59 & 69 & 28 & 2,64 & 1,06 & 10 \\
\hline & $\begin{array}{l}\text { discuss our mistakes } \\
\text { without fear. }\end{array}$ & $\%$ & 4,5 & 17,5 & 29,5 & 34 & 14 & & & \\
\hline 17 & In our university, we & $\mathrm{K}$ & 9 & 42 & 68 & 56 & 25 & 2,77 & 1.05 & 8 \\
\hline & $\begin{array}{l}\text { give feedback to } \\
\text { ourselves. }\end{array}$ & $\%$ & 4,5 & 21 & 34 & 28 & 12,5 & & & \\
\hline 18 & In our university, we & $\mathrm{K}$ & 13 & 48 & 73 & 46 & 2 & 2,94 & 1,06 & 5 \\
\hline & $\begin{array}{l}\text { prepare ourselves to } \\
\text { interact with changes } \\
\text { rapidly. }\end{array}$ & $\%$ & 6,5 & 24 & 36,5 & 23 & 10 & & & \\
\hline 19 & In our university, we & $\mathrm{k}$ & 19 & 53 & 65 & 45 & 18 & 3,05 & 1.11 & 3 \\
\hline & plan to the future. & $\%$ & 9,5 & 26,5 & 32,5 & 22 & 9 & & & \\
\hline
\end{tabular}

\begin{tabular}{|c|c|c|c|c|c|c|c|c|c|c|}
\hline \multirow[t]{2}{*}{ s } & \multirow{2}{*}{\multicolumn{2}{|c|}{ Phrase }} & \multicolumn{5}{|c|}{ Degree of Agreement } & \multirow[t]{2}{*}{ average } & \multirow{2}{*}{$\begin{array}{c}\text { Normative } \\
\text { deviation }\end{array}$} & \multirow[t]{2}{*}{ ORDER } \\
\hline & & & $\begin{array}{c}\text { Strongly } \\
\text { agree }\end{array}$ & agree & $\begin{array}{c}\text { Somehow } \\
\text { agree }\end{array}$ & Disagree & $\begin{array}{l}\text { Strongly } \\
\text { Disagree }\end{array}$ & & & \\
\hline \multicolumn{11}{|c|}{ Third dimension phrases (providing a Team Collective learning environment in the university) } \\
\hline \multirow[t]{2}{*}{20} & \multirow{2}{*}{$\begin{array}{l}\text { Our university accepts } \\
\text { different points of view } \\
\text { about work }\end{array}$} & $\mathrm{K}$ & 11 & 61 & 56 & 55 & 17 & \multirow[t]{2}{*}{2,97} & \multirow[t]{2}{*}{1,06} & \multirow[t]{2}{*}{5} \\
\hline & & $\%$ & 5,5 & 30,5 & 28 & 27,5 & 8,5 & & & \\
\hline \multirow{2}{*}{$\begin{array}{l}2 \\
1\end{array}$} & \multirow{2}{*}{$\begin{array}{l}\text { Our university presents } \\
\text { incentives to achieve } \\
\text { professional success. }\end{array}$} & $\mathrm{K}$ & 14 & 65 & 54 & 45 & 22 & \multirow[t]{2}{*}{3,02} & \multirow[t]{2}{*}{1,12} & \multirow[t]{2}{*}{3} \\
\hline & & $\%$ & 7 & 32,5 & 27 & 22,5 & 11 & & & \\
\hline \multirow[t]{2}{*}{22} & \multirow{2}{*}{$\begin{array}{l}\text { Our university accepts } \\
\text { our innovative ideas at } \\
\text { work. }\end{array}$} & $\mathrm{K}$ & 21 & 62 & 67 & 34 & 16 & \multirow[t]{2}{*}{3,19} & \multirow[t]{2}{*}{1.09} & \multirow[t]{2}{*}{1} \\
\hline & & $\%$ & 10,5 & 31 & 33,5 & 17 & 8 & & & \\
\hline \multirow[t]{2}{*}{23} & \multirow{2}{*}{$\begin{array}{l}\text { Our university } \\
\text { encourages us to try the } \\
\text { new systems at work. }\end{array}$} & $\mathrm{K}$ & 18 & 62 & 59 & 40 & 20 & \multirow[t]{2}{*}{3.09} & \multirow[t]{2}{*}{1.12} & \multirow[t]{2}{*}{2} \\
\hline & & $\%$ & 9 & 31,5 & 29,5 & 20 & 10 & & & \\
\hline \multirow[t]{2}{*}{24} & $\begin{array}{l}\text { Our university pushes us } \\
\text { towards scientific }\end{array}$ & $\mathrm{K}$ & 16 & 59 & 57 & 45 & 23 & \multirow[t]{2}{*}{3} & \multirow[t]{2}{*}{1.14} & \multirow[t]{2}{*}{4} \\
\hline & $\begin{array}{l}\text { towards scientific } \\
\text { research in work } \\
\text { problems. }\end{array}$ & $\%$ & 8 & 29,5 & 28,5 & 22,5 & 11.5 & & & \\
\hline
\end{tabular}




\begin{tabular}{|c|c|c|c|c|c|c|c|c|c|c|}
\hline \multirow[t]{2}{*}{ s } & \multirow{2}{*}{\multicolumn{2}{|c|}{ Phrase }} & \multicolumn{5}{|c|}{ Degree of Agreement } & \multirow[t]{2}{*}{ average } & \multirow{2}{*}{$\begin{array}{l}\text { Normative } \\
\text { deviation }\end{array}$} & \multirow[t]{2}{*}{ ORDER } \\
\hline & & & $\begin{array}{c}\text { Strongly } \\
\text { agree }\end{array}$ & agree & $\begin{array}{c}\text { Somehow } \\
\text { agree }\end{array}$ & Disagree & \begin{tabular}{|l} 
Strongly \\
Disagree
\end{tabular} & & & \\
\hline \multicolumn{11}{|c|}{ Fourth dimension phrases (Activating Collective participation in knowledge management)_ } \\
\hline \multirow[t]{2}{*}{25} & In our university a & $\mathrm{K}$ & 23 & 45 & 70 & 40 & 22 & \multirow[t]{2}{*}{3,3} & \multirow[t]{2}{*}{1,15} & \multirow[t]{2}{*}{2} \\
\hline & $\begin{array}{l}\text { sophisticated electronic } \\
\text { technology to store and } \\
\text { classify information in all } \\
\text { administrative levels are } \\
\text { available. }\end{array}$ & $\%$ & 11,5 & 22,5 & 35 & 20 & 11 & & & \\
\hline \multirow[t]{2}{*}{26} & We enjoy in our & $\mathrm{K}$ & 18 & 51 & 50 & 55 & 26 & \multirow[t]{2}{*}{2,90} & \multirow[t]{2}{*}{1.18} & \multirow[t]{2}{*}{4} \\
\hline & $\begin{array}{l}\text { university with full } \\
\text { authority to acquire } \\
\text { knowledge. }\end{array}$ & $\%$ & 9 & 25,5 & 25 & 27,5 & 13 & & & \\
\hline \multirow[t]{2}{*}{27} & Our university has & $\mathrm{K}$ & 26 & 52 & 51 & 49 & 22 & \multirow[t]{2}{*}{3,05} & \multirow[t]{2}{*}{1,21} & \multirow[t]{2}{*}{1} \\
\hline & $\begin{array}{l}\text { internal electronic } \\
\text { networks allow for } \\
\text { university workers get all } \\
\text { the information and data } \\
\text { concerning them. }\end{array}$ & $\%$ & 13 & 26 & 25,5 & 24,5 & 11 & & & \\
\hline \multirow[t]{2}{*}{28} & \multirow{2}{*}{$\begin{array}{l}\text { We can in our university } \\
\text { access its database easily. }\end{array}$} & $\mathrm{K}$ & 24 & 51 & 58 & 38 & 29 & \multirow[t]{2}{*}{3,01} & \multirow[t]{2}{*}{1,22} & \multirow[t]{2}{*}{3} \\
\hline & & $\%$ & 12 & 25,5 & 29 & 19 & 14,5 & & & \\
\hline \multirow[t]{2}{*}{29} & \multirow{2}{*}{$\begin{array}{l}\text { We share in our university } \\
\text { new knowledge with each } \\
\text { other and with our } \\
\text { leaders. }\end{array}$} & $\mathrm{K}$ & 12 & 49 & 65 & 48 & 26 & \multirow[t]{2}{*}{2,86} & \multirow[t]{2}{*}{1,11} & \multirow[t]{2}{*}{5} \\
\hline & & $\%$ & 6 & 24,5 & 32,5 & 24 & 13 & & & \\
\hline \multirow[t]{2}{*}{30} & \multirow{2}{*}{$\begin{array}{l}\text { We receive from our } \\
\text { university electronic } \\
\text { journals regularly. }\end{array}$} & $\mathrm{K}$ & 12 & 22 & 40 & 75 & 51 & \multirow[t]{2}{*}{2,34} & \multirow[t]{2}{*}{1,15} & \multirow[t]{2}{*}{6} \\
\hline & & $\%$ & 6 & 11 & 11 & 37,5 & 25,5 & & & \\
\hline
\end{tabular}

As shown in Table (3), the practice of the organizational learning process is happened (as low degree) at Al-Imam Muhammad Ibn Saud Islamic University, where the Arithmetic mean of the responses was (2.61 to 3.40) out of 5. The most important practice of this reality was determined through the 4 dimensional phrases, as the following: A- the first dimension (Enhancing Organizational learning): the Arithmetic mean of the responses was (3.05 out of 5). The reality represented in the faculty members' lack of knowledge about the kind of the prevalent administrative system at the university, the extent to which the administration care about exchanging experiences with international universities, its rapid accommodation with different variables, and the university possession for an organizational memory to store the university previous information and experiments. B - The second dimension (Organizing Team Learning): the Arithmetic mean of the responses was (2.91 out of 5). The reality has represented in lack of knowledge of the following: the administration job style depends on a collaborative team work, involving the university staff in planning, and making decisions and solving problems. $\mathrm{C}$ - The third dimension: (providing a team collective learning environment in the university): the Arithmetic mean of the responses was (3.05 out of 5). The reality has represented in the lack of knowledge in the following: the degree of accepting the administration for their opinions and suggestions about the work, and encourage them with prizes for creativity and innovation at work. D - The fourth dimension: (Activating collective participation in knowledge management) the Arithmetic mean of the responses was (2.86 out of 5). The reality has represented in the lack of knowledge in the following: the university possession for an improved electronic devices to store, classify information, and benefit from them, the degree of facilitating access to the university data basic, and the degree of their participation in information exchange.

These results indicate the existence of some in sufficiency in spreading the culture of the organizational learning, and the learning organization concept, the researchers attribute that to the complexities of the administrative organization of university departments, a adhering culture to traditional regulations administration, and the lack of clear strategic 
planning for the learning and teamwork processes. The reason of this may be that the University of Al-Imam Muhammad ibn Saud Islamic University is still in the beginnings of the modern management systems. And does not reach advanced levels in the area of practicing and applying these system and widely; depending on what declared in (Vice President for Studies, Development and academic accreditation, 2012) that the university has recently signed a contract with (the Stanford Institute Global U.S. Research); for the design, preparation and implementation of a comprehensive strategic plan for the University. (Suwaidan, 2012, p.58) confirmed that the organization which will succeed in the future, is the one which is benefiting from the learning capacity of all its members, collectively. (Marquardt, 2002, p. 31) has intended that will be done by enabling the organization staff, and giving them full authority to obtain knowledge, and involving them in decision-making.

By comparing the results of the first questions Answers with the results of previous studies. It found that it disagreed with the results of both: (Abu-Tineh, 2011) study on (Qatar University) where the practice of organizational learning of moderate degree. Also, the study of (Mutairi, 2010) at King Saud University, the practice of organizational learning was of moderate degree. Portfelt study (Portfelt, 2006) at (Karlstad University in Sweden), the practice of organizational learning and the availability of properties of the theoretical model of the learning organization was of medium degree.

8.2 What are the obstacles of applying organizational learning for transforming to the concept of learning organization at the University of Al-Imam Muhammad ibn Saud Islamic University from the point of view of faculty members?

To answer this question it has been used: frequencies, percentages, arithmetic means, standard deviations, and ranks style to arrange phrases.

The results of the answer to this question were as shown in Table No. (4).

Table (4) shows the opinion of the faculty members on the second axis: (obstacles to the applying of organizational learning to transforming to the concept of learning organization at the University)

\begin{tabular}{|c|c|c|c|c|c|c|c|c|c|c|}
\hline \multirow[b]{2}{*}{$\mathbf{s}$} & \multirow{2}{*}{\multicolumn{2}{|c|}{ Phrase }} & \multicolumn{5}{|c|}{ Degree of Agreement } & \multirow{2}{*}{$\begin{array}{l}\text { avera } \\
\text { ge }\end{array}$} & \multirow{2}{*}{$\begin{array}{l}\text { Normativ } \\
\text { e } \\
\text { deviation }\end{array}$} & \multirow{2}{*}{$\begin{array}{l}\text { ORD } \\
\text { ER }\end{array}$} \\
\hline & & & \multirow{2}{*}{$\begin{array}{l}\text { Strongly } \\
\text { agree }\end{array}$} & \multirow{2}{*}{$\begin{array}{l}\text { agre } \\
\text { e } \\
74\end{array}$} & \multirow{2}{*}{$\begin{array}{l}\begin{array}{l}\text { Somehow } \\
\text { agree }\end{array} \\
48 \\
\end{array}$} & \multirow{2}{*}{$\begin{array}{l}\text { Disagre } \\
\mathrm{e} \\
12\end{array}$} & \multirow{2}{*}{$\begin{array}{l}\text { Strongly } \\
\text { Disagree } \\
9\end{array}$} & & & \\
\hline \multirow{2}{*}{1} & \multirow{2}{*}{$\begin{array}{l}\text { Lack in understanding } \\
\text { the organizational } \\
\text { learning process. }\end{array}$} & $\mathrm{K}$ & & & & & & \multirow{2}{*}{3.79} & \multirow{2}{*}{1.06} & \multirow{2}{*}{4} \\
\hline & & $\%$ & 28.5 & 37 & 24 & 6 & 4.5 & & & \\
\hline \multirow[b]{2}{*}{2} & \multirow{2}{*}{$\begin{array}{l}\text { Awareness Lack about } \\
\text { the necessity to } \\
\text { transfer university to a } \\
\text { learning organization. }\end{array}$} & $\mathrm{K}$ & 49 & 84 & 44 & 17 & 6 & \multirow[b]{2}{*}{3.76} & \multirow[b]{2}{*}{1.01} & \multirow[b]{2}{*}{5} \\
\hline & & $\%$ & 24.5 & 42 & 22 & 8.5 & 3 & & & \\
\hline \multirow[b]{2}{*}{3} & \multirow{2}{*}{$\begin{array}{l}\text { I think that the learning } \\
\text { process confined to } \\
\text { the teaching in the } \\
\text { lecture hall. }\end{array}$} & $\mathrm{K}$ & 35 & 55 & 28 & 44 & 38 & \multirow[b]{2}{*}{3.02} & \multirow[b]{2}{*}{1.40} & \multirow[b]{2}{*}{18} \\
\hline & & $\%$ & 17.5 & 27.5 & 14 & 22 & 19 & & & \\
\hline \multirow{2}{*}{4} & \multirow{2}{*}{$\begin{array}{l}\text { Lack of interest in } \\
\text { learning from } \\
\text { mistakes. }\end{array}$} & $\mathrm{K}$ & 47 & 92 & 30 & 26 & 5 & \multirow{2}{*}{3.75} & \multirow{2}{*}{1.03} & \multirow{2}{*}{6} \\
\hline & & $\%$ & 23.5 & 46 & 15 & 13 & 2.5 & & & \\
\hline \multirow{2}{*}{5} & \multirow{2}{*}{$\begin{array}{l}\text { Our uninterested } \\
\text { about evaluating our } \\
\text { work performance. }\end{array}$} & $\mathrm{K}$ & 37 & 74 & 42 & 37 & 10 & \multirow{2}{*}{3.45} & \multirow{2}{*}{1.13} & \\
\hline & & $\%$ & 18.5 & 37 & 21 & 18.5 & 5 & & & 13 \\
\hline & Lack in being & $\mathrm{K}$ & 32 & 93 & 45 & 24 & 6 & & & \\
\hline 6 & $\begin{array}{l}\text { interested in self- } \\
\text { learning. }\end{array}$ & $\%$ & 16 & 46.5 & 22.5 & 12 & 3 & 3.60 & 0.991 & 9 \\
\hline & Limitation of & $\mathrm{K}$ & 53 & 87 & 36 & 18 & 6 & & & \\
\hline 7 & $\begin{array}{l}\text { experiences and } \\
\text { experiments on the } \\
\text { borders of their } \\
\text { departments. }\end{array}$ & $\%$ & 26.5 & 43.5 & 18 & 9 & 3 & 3.81 & 1.02 & 2 \\
\hline 8 & Rigidity of rules and & $\mathrm{K}$ & 51 & 88 & 42 & 13 & 6 & 3.82 & 0.984 & 1 \\
\hline
\end{tabular}




\begin{tabular}{|c|c|c|c|c|c|c|c|c|c|c|}
\hline & $\begin{array}{l}\text { lack of continuously } \\
\text { updated. }\end{array}$ & $\%$ & 25.5 & 44 & 21 & 6.5 & 3 & & & \\
\hline \multirow[b]{2}{*}{9} & \multirow{2}{*}{$\begin{array}{l}\text { Some leaders fear } \\
\text { from changing and } \\
\text { adoption of new } \\
\text { management trends. }\end{array}$} & $\mathrm{K}$ & 51 & 73 & 53 & 13 & 10 & \multirow[b]{2}{*}{3.71} & \multirow[b]{2}{*}{1.07} & \multirow[b]{2}{*}{7} \\
\hline & & $\%$ & 12 & 30.5 & 34 & 19.5 & 4 & & & \\
\hline \multirow{2}{*}{10} & \multirow{2}{*}{$\begin{array}{l}\text { Extreme centralization } \\
\text { of leadership when } \\
\text { making decisions. }\end{array}$} & $\mathrm{K}$ & 67 & 58 & 52 & 17 & 6 & \multirow{2}{*}{3.81} & \multirow{2}{*}{1.08} & \multirow{2}{*}{3} \\
\hline & & $\%$ & 33.5 & 29 & 26 & 8.5 & 3 & & & \\
\hline \multirow{2}{*}{11} & \multirow{2}{*}{$\begin{array}{l}\text { Ambiguity of the vision } \\
\text { toward the future of } \\
\text { the university }\end{array}$} & $\mathrm{K}$ & 36 & 51 & 69 & 33 & 11 & \multirow{2}{*}{3.34} & \multirow{2}{*}{1.12} & \multirow{2}{*}{17} \\
\hline & & $\%$ & 18 & 25.5 & 34.5 & 16.5 & 5.5 & & & \\
\hline \multirow[b]{2}{*}{12} & \multirow{2}{*}{$\begin{array}{l}\text { unclearness of } \\
\text { strategic among } \\
\text { workers at the } \\
\text { university. }\end{array}$} & $\mathrm{K}$ & 43 & 69 & 56 & 23 & 9 & \multirow[b]{2}{*}{3.57} & \multirow[b]{2}{*}{1.08} & \multirow[b]{2}{*}{11} \\
\hline & & $\%$ & 21.5 & 34.5 & 28 & 11.5 & 4.5 & & & \\
\hline \multirow[b]{2}{*}{13} & \multirow{2}{*}{$\begin{array}{l}\text { Poorness of system } \\
\text { encourages } \\
\text { employees to be } \\
\text { creativity. }\end{array}$} & $\mathrm{K}$ & 57 & 55 & 50 & 34 & 4 & \multirow[b]{2}{*}{3.63} & \multirow[b]{2}{*}{1.12} & \multirow[b]{2}{*}{8} \\
\hline & & $\%$ & 28.5 & 27.5 & 25 & 17 & 2 & & & \\
\hline \multirow{2}{*}{14} & \multirow{2}{*}{$\begin{array}{l}\text { The university staff } \\
\text { avoids teamwork. }\end{array}$} & $\mathrm{K}$ & 34 & 62 & 65 & 35 & 4 & \multirow{2}{*}{3.43} & \multirow{2}{*}{1.03} & \multirow{2}{*}{14} \\
\hline & & $\%$ & 17 & 31 & 32.5 & 17.5 & 2 & & & \\
\hline \multirow[b]{2}{*}{15} & \multirow{2}{*}{$\begin{array}{l}\text { The difficulty of } \\
\text { obtaining the previous } \\
\text { experiences of the } \\
\text { University. }\end{array}$} & $\mathrm{K}$ & 38 & 75 & 51 & 28 & 8 & \multirow[b]{2}{*}{3.53} & & \\
\hline & & $\%$ & 19 & 37.5 & 25.5 & 14 & 4 & & 1.07 & 12 \\
\hline 16 & $\begin{array}{l}\text { Limited capabilities, } \\
\text { equipment and } \\
\text { technologies that help } \\
\text { acquiring knowledge. }\end{array}$ & K & 47 & 52 & 43 & 46 & 12 & 3.38 & 1.023 & 16 \\
\hline & & $\%$ & 23.5 & 26 & 21.5 & 23 & 6 & & & \\
\hline & Lack of authority & $\mathrm{K}$ & 43 & 74 & 48 & 31 & 4 & & & \\
\hline 17 & $\begin{array}{l}\text { employees to access } \\
\text { the information stored } \\
\text { on their work }\end{array}$ & $\%$ & 21.5 & 37 & 24 & 15.5 & 2 & 3.60 & 1.05 & 10 \\
\hline & lack of communication & $\mathrm{K}$ & 40 & 62 & 51 & 39 & 8 & & & \\
\hline 18 & $\begin{array}{l}\text { and other local and } \\
\text { international } \\
\text { universities to get } \\
\text { benefit. }\end{array}$ & $\%$ & 20 & 31 & 25.5 & 19.5 & 4 & 3.43 & 1.13 & 15 \\
\hline
\end{tabular}

As shown in Table (4), the existence of obstacles was (of high degree) which limits applying the organizational learning for transforming to the learning organization concept at Al-Imam Muhammad Ibn Saud Islamic University with Arithmetic mean of (3.58 out of 5). The most important obstacles represented in: the lack of renewing administrative systems, the fear of some leaders from changing and when making decisions, the limitation of the individuals experiences on their departments and their avoidance for teamwork, and the limitation of using modern techniques in knowledge management between all the staff.

These results indicated the faculty members' recognition and awareness about the existence of obstacles. The researchers return this result, to the existence of an isolated administrate on between departments, the lack of interesting in spending the recent management concepts among workers, and the lack of owning a faculty member for a sufficient time to learn. Both (al-Baghdadi and al-Abadi, 2010, p.40) and (Abukhaddar, in 2007, p.79 -82), indicated that the most important obstacles exist in the large number of functional burdens, the limitation of available time for a chivying them, the 
lack of availability of a favorable environment for learning, and the lack of availability of methods, tools and techniques that are helping in learning and knowledge acquisition.

Also, has been found that there is a (consensus) among the results of the second axis of obstacles, with the results of the first axis of the organizational learning at university. It exists particularly in the answers to the first axis, which showed a lack of knowledge of faculty members about the degree of the enhancing process of the organizational learning, in line with the result of the second axis in terms of a lack of understanding the process of the organizational learning and fear some leaders from changing and exercising extreme centralization in decision-making.

In comparing the results of the second questions Answers with the results of previous studies. It found that it had agreed with the results of both studies: (Mutairi, 2010) at (King Saud University), in that the most important obstacle which limits practicing the organizational learning is the lack of training in the field of organizational learning, and (Portfelt,2006) study at (Karlstad University in Sweden), where the most important obstacles were as follows: The neglecting of the feedback, and the lack of information on the internal environment for the work of the university.

8.3 What are the suggestions that may contribute in applying organizational learning, for transforming to the concept of learning organization at the University of Al-Imam Muhammad ibn Saud Islamic University from the point of view of faculty members?

To answer this question it has been used : frequencies, percentages, arithmetic means, standard deviations, and ranks style to arrange phrases.

The results of the answer to this question were as shown in Table No. (5).

Table 5 shows the opinion of the faculty members on the third axis: (the suggestions that may contribute in applying organizational learning, for transforming to the concept of learning organization at the University).

\begin{tabular}{|c|c|c|c|c|c|c|c|c|c|c|}
\hline \multirow[b]{2}{*}{$\mathbf{s}$} & \multirow{2}{*}{\multicolumn{2}{|c|}{ Phrase }} & \multicolumn{5}{|c|}{ Degree of Agreement } & \multirow[b]{2}{*}{ average } & \multirow{2}{*}{$\begin{array}{l}\text { Normative } \\
\text { deviation }\end{array}$} & \multirow[b]{2}{*}{ ORDER } \\
\hline & & & \multirow{2}{*}{$\begin{array}{c}\begin{array}{c}\text { Strongly } \\
\text { agree }\end{array} \\
113 \\
\end{array}$} & \multirow{2}{*}{\begin{tabular}{|c|} 
agree \\
64 \\
\end{tabular}} & \multirow{2}{*}{$\begin{array}{c}\begin{array}{c}\text { Somehow } \\
\text { agree }\end{array} \\
14\end{array}$} & \multirow{2}{*}{\begin{tabular}{|c|} 
Disagree \\
9
\end{tabular}} & \multirow{2}{*}{$\begin{array}{c}\text { Strongly } \\
\text { Disagree } \\
0\end{array}$} & & & \\
\hline & The interest in spreading a & $\mathrm{K}$ & & & & & & \multirow[b]{2}{*}{4.40} & \multirow[b]{2}{*}{0.808} & \multirow[b]{2}{*}{11} \\
\hline 1 & $\begin{array}{l}\text { learning among } \\
\text { employees at the } \\
\text { university. }\end{array}$ & $\%$ & 56.6 & 32 & 7 & 4.5 & 0 & & & \\
\hline \multirow[b]{2}{*}{2} & Directing staff at the & $\mathrm{K}$ & 106 & 71 & 20 & 3 & 0 & \multirow[b]{2}{*}{4.40} & \multirow[b]{2}{*}{0.729} & \multirow[b]{2}{*}{10} \\
\hline & $\begin{array}{l}\text { importance of transforming } \\
\text { to the learning } \\
\text { organization. }\end{array}$ & $\%$ & 53 & 35.5 & 10 & 1.5 & 0 & & & \\
\hline \multirow{2}{*}{3} & Involvement of individuals & $\mathrm{K}$ & 121 & 58 & 15 & 6 & 0 & \multirow{2}{*}{4.47} & \multirow{2}{*}{0.762} & \multirow{2}{*}{8} \\
\hline & $\begin{array}{c}\text { In shaping the future vision } \\
\text { of the University }\end{array}$ & $\%$ & 60.5 & 29 & 7.5 & 3 & 0 & & & \\
\hline \multirow[b]{2}{*}{4} & \multirow{2}{*}{$\begin{array}{c}\text { Renewal of the rules, } \\
\text { regulations, and } \\
\text { administrative procedures } \\
\text { to meet the various } \\
\text { competitions. }\end{array}$} & $\mathrm{K}$ & 123 & 57 & 12 & 5 & 0 & \multirow[b]{2}{*}{4.49} & \multirow[b]{2}{*}{0.743} & \multirow[b]{2}{*}{5} \\
\hline & & $\%$ & 61.5 & 28.5 & 6 & 2.5 & 0 & & & \\
\hline \multirow[b]{2}{*}{5} & Using the latest & $\mathrm{K}$ & 132 & 51 & 13 & 5 & 0 & \multirow[b]{2}{*}{4.55} & \multirow[b]{2}{*}{0.721} & \multirow[b]{2}{*}{2} \\
\hline & $\begin{array}{c}\text { devices in the training in } \\
\text { the workplace. }\end{array}$ & $\%$ & 66 & 25.5 & 6.5 & 2.5 & 0 & & & \\
\hline \multirow[b]{2}{*}{6} & Continuous evaluation for & $\mathrm{K}$ & 119 & 62 & 14 & 6 & 0 & \multirow[b]{2}{*}{4.47} & \multirow[b]{2}{*}{0.749} & \multirow[b]{2}{*}{7} \\
\hline & $\begin{array}{c}\begin{array}{c}\text { performance in order to } \\
\text { improve it. }\end{array} \\
\end{array}$ & $\%$ & 59.5 & 31 & 7 & 3 & 0 & & & \\
\hline \multirow{2}{*}{7} & Abandon old & $\mathrm{K}$ & 131 & 53 & 18 & 2 & 0 & 156 & 0660 & 1 \\
\hline & and accepting changing. & $\%$ & 65.5 & 26.5 & 9 & 1 & 0 & 4.50 & 0.069 & 1 \\
\hline
\end{tabular}




\begin{tabular}{|c|c|c|c|c|c|c|c|c|c|c|}
\hline \multirow{2}{*}{8} & \multirow{2}{*}{$\begin{array}{c}\text { Employee participation in } \\
\text { decision-making. }\end{array}$} & $\mathrm{K}$ & 111 & 69 & 18 & 2 & 0 & \multirow{2}{*}{4.44} & \multirow{2}{*}{0.669} & \multirow{2}{*}{9} \\
\hline & & $\%$ & 55.5 & 34.5 & 9 & 1 & 0 & & & \\
\hline \multirow{2}{*}{9} & \multirow{2}{*}{$\begin{array}{l}\text { Encouraging staff to } \\
\text { highlight the truth and } \\
\text { admitting mistakes. }\end{array}$} & $\mathrm{K}$ & 114 & 67 & 18 & 1 & 0 & \multirow{2}{*}{4.47} & \multirow{2}{*}{0.679} & \multirow{2}{*}{6} \\
\hline & & $\%$ & 57 & 33.5 & 9 & 0.5 & 0 & & & \\
\hline \multirow[b]{2}{*}{10} & \multirow{2}{*}{$\begin{array}{l}\text { Creating systems to } \\
\text { identify, record } \\
\text { information, data and } \\
\text { consistently university } \\
\text { experience }\end{array}$} & $\mathrm{K}$ & 118 & 68 & 14 & 0 & 0 & \multirow[b]{2}{*}{4.52} & \multirow[b]{2}{*}{0.625} & \multirow[b]{2}{*}{4} \\
\hline & & $\%$ & 59 & 34 & 7 & 0 & 0 & & & \\
\hline \multirow[b]{2}{*}{11} & \multirow{2}{*}{$\begin{array}{c}\text { Organizing periodic } \\
\text { meetings between } \\
\text { employees at all levels of } \\
\text { the university to exchange } \\
\text { information and discuss } \\
\text { issues and problems. }\end{array}$} & $\mathrm{K}$ & 102 & 80 & 13 & 5 & 0 & \multirow[b]{2}{*}{4.39} & \multirow[b]{2}{*}{0.722} & \multirow[b]{2}{*}{12} \\
\hline & & $\%$ & 51 & 40 & 6.5 & 2.5 & 0 & & & \\
\hline \multirow[b]{2}{*}{12} & \multirow{2}{*}{$\begin{array}{c}\text { Activating cooperation with } \\
\text { local and international } \\
\text { universities } \\
\text { and benefit from their } \\
\text { experiences. }\end{array}$} & $\mathrm{K}$ & 123 & 63 & 13 & 1 & 0 & \multirow[b]{2}{*}{4.53} & \multirow[b]{2}{*}{0.664} & \multirow[b]{2}{*}{3} \\
\hline & & $\%$ & 61.5 & 31.5 & 6.5 & 0.5 & 0 & & & \\
\hline \multicolumn{11}{|c|}{ Arithmetic mean $=(4.47)$ Standard Deviation $=(0.573)$} \\
\hline
\end{tabular}

As shown in table (5), the results of question three answers indicated, and accepting the suggestions (of very high degree) which may contribute in applying the organizational learning process at Al-Imam Muhammad Ibn Saud Islamic University with Arithmetic mean of (4.47 out of 5). The most important suggestions represented as the following: Accepting the administration for changing, using the cooperation administration for modern techniques in training at job locations, the cooperation with the local and international universities to benefit from their developmental experiments, and encouraging the staff to admit their mistakes and learn from them.

The results pointed to the faculty members' acceptance for applying the organizational learning process for transforming the university to a learning organization, and the existence of large motivation for changing the traditional administration. The researchers interpret this interest in learning that it's may be from reality of their work in teaching profession and university education.

Elmelegy (2011, p.231) noted in the same context that the best entrances for applying the concept of learning organizations to universities, is organizational learning which focuses on promoting learning processes, participation, creativity and collective interaction between employees of the university.

By comparing the results of the third questions Answers with the results of previous studies. It found that it had agreed with (Reece, 2004) study on the (Australian universities) in terms of agreeing that more properties of the learning organization at university are: leadership, shared vision, and the availability of the organizational culture.

8.4 Are there statically significant differences at level of (0.05) or less, between the point of views of the faculty members on: the reality of organizational learning, its applying obstacles, and suggestions that may contribute in applying it at the University of Al-Imam Muhammad ibn Saud Islamic University, according to differences in their personality and professional variables (sex, grade, years of experience, and specialization)?

To answer this question, (P- test) has been used which is (One-Way ANOVA), to clarify the statistically significant differences at level $(0.05)$ or less, for the responses of faculty members about study axes, according to differences of these variables: (sex, Degree, years of experience, specialization).Also,(T-test) has been used to know the significant differences among the means according to the variables: ( sex, specialization ).

The results of the answers to the fourth question are shown in tables (6) to (9) as follows: 
Table 6: shows the statically differences among the faculty members points of view about the study axes using (T-test) according the difference in the variable of gender.

\begin{tabular}{|c|c|c|c|c|c|c|}
\hline statement & $\begin{array}{l}\text { Test } \\
\text { type }\end{array}$ & $\begin{array}{l}\text { Arithmetic } \\
\text { mean }\end{array}$ & $\begin{array}{l}\text { Standard } \\
\text { Deviation }\end{array}$ & $\begin{array}{l}\text { Freedom } \\
\text { degree }\end{array}$ & T value & $\begin{array}{l}\text { Statistical } \\
\text { significance }\end{array}$ \\
\hline \multirow[t]{2}{*}{ (first dimension) of the first axis } & male & 2.95 & 0.852 & \multirow{2}{*}{198} & \multirow{2}{*}{$2.221-$} & \multirow{2}{*}{$0.035^{*}$} \\
\hline & female & 3.21 & 0.817 & & & \\
\hline \multirow[t]{2}{*}{ (second dimension) of the first axis } & male & 2.82 & 0.889 & \multirow{2}{*}{198} & \multirow{2}{*}{$1.811-$} & \multirow{2}{*}{0.072} \\
\hline & female & 2.94 & 0.856 & & & \\
\hline \multirow[t]{2}{*}{ (third dimension) of the first axis } & male & 3.32 & 0.987 & \multirow[b]{2}{*}{198} & \multirow{2}{*}{$2.144-$} & \multirow{2}{*}{$* 0.033$} \\
\hline & female & 2.84 & 0.853 & & & \\
\hline \multirow[t]{2}{*}{ (Fourth dimension) of the first axis } & male & 2.91 & 0.950 & \multirow{2}{*}{198} & \multirow{2}{*}{$0.484-$} & \multirow{2}{*}{0.627} \\
\hline & female & 3.68 & 0.899 & & & \\
\hline \multirow[t]{2}{*}{ Second axis (obstacles) } & male & 3.41 & 0.722 & \multirow{2}{*}{198} & \multirow{2}{*}{$2.624-$} & \multirow{2}{*}{$0.009^{*}$} \\
\hline & female & 3.41 & 0.699 & & & \\
\hline \multirow[t]{2}{*}{ Third axis (suggestions) } & male & 4.51 & 0.497 & \multirow{2}{*}{198} & \multirow{2}{*}{1.237} & \multirow{2}{*}{0.218} \\
\hline & female & 4.41 & 0.678 & & & \\
\hline
\end{tabular}

Through Table (6) it is clear that the results of the study showed results about the differences between the points of view: The existing of statistically significant differences at level (0.05) or less in favor of female respondents in promoting the organizational learning process, and providing team learning environment. The cause of these differences my related to the multiplicity of female students centers and their three branches in side Riyadh city and the administrative isolation in each center. Also there are differences in favor of male respondents in obstacles when applying the organizational learning, which may related to the administrative and traditional systems, and the weakness of technical communication between different departments within the same college. Also there are not any statistically significant differences from males and females point of view on the (Enhancing Organizational learning) and on (Activating Collective participation in knowledge management). The researchers attribute that to the awareness of both genders about the concept of teamwork, and the importance of using modern technologies in knowledge management. There are no statistically significant differences from males and females point of views on the third axis: the suggestion. The researchers justify the lack of differences both genders are belonging to the same university, and they are looking forward to its development.

Table 7 shows the results of analysis of (P- test) (One-Way ANOVA) for the differences between the faculty members point of views on the axes according to study different variable Degree

\begin{tabular}{|c|c|c|c|c|c|c|}
\hline Axes & Difference sources & $\begin{array}{l}\text { Total } \\
\text { quarters }\end{array}$ & $\begin{array}{l}\begin{array}{l}\text { Freedom } \\
\text { degree }\end{array} \\
\end{array}$ & $\begin{array}{l}\text { Quarters } \\
\text { average }\end{array}$ & F value & $\begin{array}{l}\text { Statistical } \\
\text { significance }\end{array}$ \\
\hline \multirow{2}{*}{$\begin{array}{l}\text { (first dimension) of } \\
\text { the first axis }\end{array}$} & Among groups & 0.075 & 2 & \multirow{2}{*}{0.037} & \multirow{2}{*}{0.052} & \multirow{2}{*}{0.950} \\
\hline & Inside groups & 142.637 & 197 & & & \\
\hline \multirow{2}{*}{$\begin{array}{l}\text { (second dimension) } \\
\text { of the first axis }\end{array}$} & Among groups & 0.091 & 2 & \multirow{2}{*}{0.045} & \multirow{2}{*}{0.058} & \multirow{2}{*}{0.944} \\
\hline & Inside groups & 154.554 & 197 & & & \\
\hline \multirow{2}{*}{$\begin{array}{l}\text { (third dimension) of } \\
\text { the first axis }\end{array}$} & Among groups & 0.027 & 2 & \multirow{2}{*}{0.14} & \multirow{2}{*}{0.015} & \multirow{2}{*}{0.985} \\
\hline & Inside groups & 178.306 & 197 & & & \\
\hline \multirow{2}{*}{$\begin{array}{l}\text { (Fourth dimension) } \\
\text { of the first axis }\end{array}$} & Among groups & 0.200 & 2 & \multirow{2}{*}{$\begin{array}{l}0.100 \\
0.873\end{array}$} & \multirow{2}{*}{0.115} & \multirow{2}{*}{0.892} \\
\hline & Inside groups & 171.905 & 197 & & & \\
\hline \multirow{2}{*}{$\begin{array}{l}\text { Second axis } \\
\text { (obstacles) }\end{array}$} & Among groups & 0.201 & 2 & \multirow{2}{*}{0.100} & \multirow{2}{*}{0.190} & \multirow{2}{*}{0.827} \\
\hline & Inside groups & 104.286 & 197 & & & \\
\hline \multirow{2}{*}{$\begin{array}{l}\text { Third axis } \\
\text { (suggestions) }\end{array}$} & Among groups & 0.109 & 2 & \multirow[t]{2}{*}{0.055} & \multirow{2}{*}{0.165} & \multirow{2}{*}{0.848} \\
\hline & Inside groups & 65.876 & 197 & & & \\
\hline
\end{tabular}


From table (7), the results intended that there is no statistically significant differences at level $(0.05)$ or less, in the views on all following study axes: (Reality of the organizational learning, its applying obstacles, the suggestions which may contribute in applying it) in accordance to the (scientific degree), whether the member: (Professor - Associate Professor - Assistant Professor). The researchers attribute this result because of the entire faculty members are belonging to the same university, and therefore all of them agree in defining the reality, face the same obstacles and also interested in all suggestions that may contribute in university development and progress.

Table 8shows the results of analysis of (P- test) (One-Way ANOVA) for the differences between the faculty members point of view on the axes according to study different variable (years of experience).

\begin{tabular}{|c|c|c|c|c|c|c|}
\hline Axes & Difference sources & $\begin{array}{l}\text { Total } \\
\text { quarters }\end{array}$ & $\begin{array}{l}\text { Freedom } \\
\text { degree }\end{array}$ & $\begin{array}{l}\text { Quarters } \\
\text { average }\end{array}$ & F-value & $\begin{array}{l}\text { Statistical } \\
\text { significance }\end{array}$ \\
\hline \multirow{2}{*}{$\begin{array}{l}\text { (first dimension) of } \\
\text { the first axis }\end{array}$} & Among groups & 0.075 & 2 & \multirow{2}{*}{0.037} & \multirow{2}{*}{1.067} & \multirow{2}{*}{0.364} \\
\hline & Inside groups & 142.637 & 197 & & & \\
\hline \multirow{2}{*}{$\begin{array}{l}\text { (second dimension) } \\
\text { of the first axis }\end{array}$} & Among groups & 0.091 & 2 & \multirow{2}{*}{0.045} & \multirow{2}{*}{1.386} & \multirow{2}{*}{0.348} \\
\hline & Inside groups & 154.554 & 197 & & & \\
\hline \multirow{2}{*}{$\begin{array}{l}\text { (third dimension) of } \\
\text { the first axis }\end{array}$} & Among groups & 0.027 & 2 & \multirow{2}{*}{0.14} & \multirow{2}{*}{0.605} & \multirow{2}{*}{0.631} \\
\hline & Inside groups & 178.306 & 197 & & & \\
\hline \multirow{2}{*}{$\begin{array}{l}\text { (Fourth dimension) } \\
\text { of the first axis }\end{array}$} & Among groups & 0.200 & 2 & \multirow{2}{*}{0.010} & \multirow{2}{*}{0.722} & \multirow{2}{*}{0.540} \\
\hline & Inside groups & 171.905 & 197 & & & \\
\hline \multirow{2}{*}{$\begin{array}{l}\text { Second axis } \\
\text { (obstacles) }\end{array}$} & Among groups & 0.201 & 2 & \multirow{2}{*}{0.100} & \multirow{2}{*}{0.430} & \multirow{2}{*}{0.732} \\
\hline & Inside groups & 104.286 & 197 & & & \\
\hline \multirow{2}{*}{$\begin{array}{l}\text { Third axis } \\
\text { (suggestions) }\end{array}$} & Among groups & 0.109 & 2 & \multirow[t]{2}{*}{0.055} & \multirow{2}{*}{1.677} & \multirow{2}{*}{0.173} \\
\hline & Inside groups & 65.876 & 197 & & & \\
\hline
\end{tabular}

Through Table (8) the results of the study showed no statistically significant differences at level (0.05) or less, in the views on the all the study axes, where it is noted that they were not affected by differences in the number of years of experience. The researchers attribute that for applying the university traditional administrative systems that never changed or renewed, The evidence for this is that most members in the number of years of experience did not notice any change in the used administrative system.

Table 9 shows statistical differences between the faculty point of views about axes study using (T-test) according to the different variable of (specialization)

\begin{tabular}{|c|c|c|c|c|}
\hline statement & Test type & Freedom degree & $\mathrm{T}$-value & $\begin{array}{l}\text { Statistical } \\
\text { significance }\end{array}$ \\
\hline \multirow[t]{2}{*}{ (first dimension) of the first axis } & Humanities & \multirow[t]{2}{*}{198} & \multirow{2}{*}{$0.955-$} & \multirow{2}{*}{0.341} \\
\hline & natural sciences & & & \\
\hline \multirow[t]{2}{*}{ (second dimension) of the first axis } & Humanities & \multirow[t]{2}{*}{198} & \multirow{2}{*}{$1.035-$} & \multirow{2}{*}{0.302} \\
\hline & natural sciences & & & \\
\hline \multirow[t]{2}{*}{ (third dimension) of the first axis } & Humanities & \multirow[t]{2}{*}{198} & \multirow{2}{*}{$0.569-$} & \multirow{2}{*}{0.570} \\
\hline & natural sciences & & & \\
\hline \multirow[t]{2}{*}{ (Fourth dimension) of the first axis } & Humanities & \multirow[t]{2}{*}{198} & \multirow{2}{*}{$0.164-$} & \multirow{2}{*}{0.870} \\
\hline & natural sciences & & & \\
\hline \multirow{2}{*}{$\begin{array}{l}\text { Second axis } \\
\text { (obstacles) }\end{array}$} & Humanities & \multirow[t]{2}{*}{198} & \multirow{2}{*}{0.559} & \multirow{2}{*}{0.577} \\
\hline & natural sciences & & & \\
\hline \multirow{2}{*}{$\begin{array}{l}\text { Third axis } \\
\text { (suggestions) }\end{array}$} & Humanities & \multirow[t]{2}{*}{198} & \multirow{2}{*}{2.176} & \multirow{2}{*}{$0.031 *$} \\
\hline & natural sciences & & & \\
\hline
\end{tabular}


Through Table (9), it is clear that there are statistically significant differences at level $(0.05)$ or less in favor of the Humanities Sciences specialties in the suggestions of applying the organizational learning. The researchers explain that, the cause of these differences may related to the existence of some decrease in the administrative organizing in the Humanities Sciences, (9) colleges, compared to (4) colleges of natural Sciences. And most of them have lack in activate benefiting from the modern techniques in knowledge management.In comparison the results of the fourth questions Answers with the results of previous studies. It found that it differed with the study result of (Mutairi, 2010) on (King Saud University), in the absence of statistically significant differences between the participants in the sex variable, and also in the presence of statistically significant differences among the participants of faculty members and administrators in the experience variable, for the benefit of individuals in the number of years of experience.

\section{Recommendations}

In light of the results of the study which have been reached, the theoretical framework, and previous studies, the researchers offered some recommendations and suggestions that may contribute in the attention interest in applying the organizational learning to transform to the concept of learning organization at the universities, as the following:

\section{A- Recommendations for the decision makers and the academic leaders in the universities by:}

1- By spreading the culture of the organizational learning and the concept of the learning organization among the faculty members, the staff, and administrators at the university; by holding training courses and workshops, which study the experiments of universities which applied the organizational learning to benefit from them.

2- By providing a supported environment to facilitate the organizational learning process at the university using the teamwork approach. Also, this can happen by making internal learning networks between all the college, and external networks with local and international universities for the exchange of knowledge, experiments and information.

3- By establishing specialized academic departments in the learning organizations and the organizational learning sciences at the universities. Also making centers for the organizational learning inside the university, present educational programs for the postgraduate stage, grant diploma specialized in organization sciences, where universities students, external organizations members as: banks, companies, and offer different consulting.

\section{B- Recommendation for all the staff at the universities}

To make contributions specially from specialists in the educational planning and administration sciences, by holding cultural lectures for all the staff at the university, to encourage them to determine their needs from the learning process and on giving their thoughts, points of view and their suggestions in order to contribute in the university development.

\section{C- Recommendation for the researchers and students in the educational administrative sciences}

1- By Making a comparative study with international universities which had applied the organizational learning for transferring to the learning organization in order to get benefits from their experiences.

2- By making studies about designing training programs for applying the organizational learning process to all the staff at the universities.

\section{References}

Abu khaddar, Eman. (2007), Organizational learning and learning organization. Administrative directions for the development of modern organizations 21. Dar Al moyaed for publishing, Riyadh, KSA.

Abu Nasr, M. (2000), Knowledge management and learning organizations. Arab Group for the training and deployment, Egypt.

Abu Shandi, Saad. (2011), Human resources management in educational institutions. Osama for Publishing and Distribution, Jordan.

Abu-Tineh, Abdullah M. (2011), (Exploring the relationship between organizational learning and career resilience among faculty members at Qatar University) (Electronic version). International Journal of Educational Management .Vol. 25 No. 6, 2011 pp. 635-650. q Emerald Group Publishing Limited.0951-354X.DOI 10.1108/09513541111159095. 
Ahmed, Shaker. (2005), TQM and excellence of the university. Fifth Educational Conference, quality of university education Journal, Vol.1 No. 3, pp 312-320. Bahrain.

Al-Assaf, Saleh. (2006), The approach to the research in the behavioral sciences, Obeikan for publishing. Riyadh, KSA.

Alhawagerh, Kamel. (2010), Concept of the learning organization in Jordanian universities from the faculty members point of view. Jordan Journal of Business Administration, Vol.6 No.1. pp. 10-18.

Elmelegy, Reda. (2011), Knowledge management and organizational learning university approach in the knowledge society, Taiba for publication, Cairo.

Ayoub, N. (2004), the role of the practice of organizational learning in support change strategies in major installations Saudi Arabia, the Institute of Public Administration Journal, Vol. 44, No. 1, pp. 63 - 134.

Baghdadi, Adil; Abadi, Hashim. (2010), Organizational learning and learning organization and their relationship to the contemporary administrative concepts, Warraq for Publishing, Jordan.

Davis, D \& Daley,B. J.(2008), (The learning organization and its dimensions as key factors in firms' performance), Human Resource Development International Journal, Vol. 11, No. 1: 51.

ECLO.( 2012), (European Consortium for the Learning Organization), Retrieve Mars 3, 2012, from: www.eclo.org.

Gibran, Ali.(2011), School as an learning and Director as an educational leader from the teachers point of view in Jordan, Islamic University Journal, Vol. 19, No. 1, pp. 427-458.

Goodyear, M.Ames, Oliver,K. and Russell. (2006), (Organizational Strategies for Fostering a Culture of Learning: A Vision of Organizational Learning).pg, 3.EDUCAUSE.E-book, Available electronically at www.educause.edu/cultivatingcareers, ISBN 0-9672853-5-6.

Hamoud, K. (2010), Organization of knowledge, Jordan: Safa for Publishing, Jordan.

Hussein, salama. (2007), Knowledge management: as an input to improve the quality of higher education institutions. Vision for the future, and a working paper submitted to the first annual conference of the Arab Center for Learning and Development, in collaboration with the University of Ain Shams, which was held in Egypt from May 3 to 5 (2004), Vol. I.

Lancaster University. (2012), (Lancaster University: Center for thestudy of Technology and organization (CSTO)), Retrieve February 26, 2012, from: www.lums.lancs.ac.uk/research/centres/csto

Manlow, V. Friedman, H.L. (2010), Inventing the Future: Using the New Media to Transform a University From a Teaching Organization to a Learning Organization. Journal of Interactive Learning Research, Vol. 21, No. 1, pp. 47-64

Marquardt, Michael J. (2002), Building the Learning Organization: Mastering the Five Element for corporate Learning, DaviesBlack Inc.Publishing company, Palo Alto, USA.

Mutairi, M. (2010), Organizational learning at King Saud University from the workers at the university point of view, Unpublished Master's Thesis, Department of Public Administration, College of Business Administration, King Saud University, Riyadh, KSA.

Portfelt, Ingela. (2006), (The University; A Learning Organization). Unpublished Ph.D thesis, Karlstad University. SWEDEN.( Karlstad University Studies 2006:23).ISSN 1403-8099.ISBN 91-7063-054-2.

Reece, Philip.(2004), (Universities as learning organizations: how can Australian universities become learning organizations?), Unpublished Ph.D thesis, Murdoch University , Perth, western Australia.

Senge, Peter M. (1990), The Fifth Discipline: The Art \& Practice of The Learning Organization, Currency Doubleday, New York. USA.

SOL. (2012), (The international Society for Organizational Learning), Retrieve Mars 3, 2012, from: www. solonline.org

Sultan, Susan; Khadr, Doha. (2010), Educational institutions as Learning Organizations, AL-Fiker for Publishing, Jordan.

Sweden, Tariq. (2012), Recent trends in management, Cordoba for Publishing, Riyadh, KSA.

The Ministry of Economy and Planning. (2010), Ninth Development Plan for the years Publication (2010-2014), Riyadh, KSA.

The Ministry of Higher Education. (2011), Arabia Universities Guide. The version of the Department of Public Relations and Media, Riyadh, KSA, p 9 - 25.

The University of Kansas. (2012), (About The University of Kansas), Retrieve February 23, 2012, from: www.ku.edu/about/ku

Tail, Majdi. (2006), (output graduate programs contribute to the development requirements) research presented to a graduate seminar and development plans held at the University of Al-Imam Muhammad ibn Saud Islamic University, Riyadh, KSA.

Taweel, Hani; Ababneh, Saleh. (2009), learning school: School of the Future, Wael for Publishing, Jordan.

University of Al-Imam Muhammad ibn Saud Islamic studies, development and academic accreditation. (2011), Retrieved on (13/8/2011) on the link: www.imamu.edu.sa

University of Al-Imam Muhammad ibn Saud Islamic University. (2011), Statistics of the University faculty numbers (2010), Retrieved on (13/8/2011) on the link: www.imamu.edu.sa

Weldy, T. G. (2009), (Learning organization and transfer: strategies for improving performance), The Learning Organization Journal, Vol. 16, No. 1, pp. 58-68.

Zayed, Nasser, et al. (2009), Learning Organization and its applying in Saudi Arabia, "a case study on the key sectors of the Royal Commission for Jubail" from the leaves of Action of the International Conference for Administrative Development "towards outstanding performance in the public sector", which was held in Riyadh from 1-4 November (2009). 